\title{
KEMAMPUAN LITERASI SAINS SISWA SMA DI KOTA KENDARI: DESKRIPSI DAN ANALYSIS
}

\author{
Erniwati $^{1}$, Istijarah ${ }^{2}$, La Tahang ${ }^{3}$, Hunaidah ${ }^{4}$, Vivi Hastuti Rufa Mongkito ${ }^{5}$, \\ Suritno Fayanto ${ }^{6 *}$ \\ 1,3,4,5 Jurusan Pendidikan Fisika, Universitas Halu Oleo \\ e-mail ${ }^{1}$ :erniwati@uho.ac.id, e-mail ${ }^{3}$ :latahang@uho.ac.id,e-mail ${ }^{4}$ :hunaidah@uho.ac.id, \\ email ${ }^{5}$ :vivihastuti@uho.ac.id \\ ${ }^{2,6}$ SMA Tahfidzul Qur;an Mu'adz Bin Jabal Kendari \\ e-mail ${ }^{2}:$ istijarah@gmail.com ,e-mail ${ }^{6^{*}}:$ suritnofayanto@gmail.com
}

\begin{tabular}{|l|l|l|l}
\hline Diterima 20 Juli 2020 & Direvisi 9 Agustus 2020 & Disetujui 11 Agustus 2020 & Dipublikasikan 29 Agustus 2020 \\
\hline
\end{tabular}
https://doi.org/10.33369/jkf.3.2.99-108

\begin{abstract}
ABSTRAK
Tujuan dari kajian ini adalah memberikan gambaran kemampuan literasi sains siswa SMA khusunya di kota Kendari. Subjek penelitian terpusat di SMA 1 Kendari dengan total subjek sebanyak 350 orang. Topik pelajaran yang digunakan adalah energi. Jenis penelitian ini menggunakan deskriptif dengan pendekatan kuantitatif. Teknik pengumpalan data menggunaka tes yang didalamnya meliputi aspek kontek, konten, dan proses. Sedangkan teknik analisis data menggunakan statustuf deskriptif. Hasil investigasi diperoleh bahwa Kemampuan literasi sains peserta didik kelas X di SMAN 1 Kendari pada indicator aspek konten dimana indicator pertama yaitu perubahan energy memperoleh nilai presentase $70,83 \%$ dengan kategori cukup. Kemudian untuk indicator bahan bakar alternative memperoleh nilai presentase $79,72 \%$ dengan kategori baik. Sedangkan untuk indicator molekul penyedia energi memperoleh nilai presentase 33,75\% dengan kategori sangat rendah. Kemampuan literasi sains peserta didik kelas X di SMAN 1 Kendari pada indicator aspek proses dimana pada indicator pertama mengidentifikasi isu ilmiah memperoleh nilai presentase $50,13 \%$ dengan rendah. Kemudian untuk indicator menjelaskan fenomena ilmiah memperoleh nilai presentase 34,62\% dengan kategori sangat rendah. Sedangkan untuk indicator menggunakan bukti ilmiah memperoleh nilai presentase 52,69\% dengan kategori rendah. Sedangkan kemampuan literasi sains peserta didik kelas X di SMAN 1 Kendari pada indicator aspek konteks dimana pada indicator pertama aplikasi energi bidang teknologi memperoleh nilai presentase $89,72 \%$ dengan kategori sangat baik. Kemudian untuk indicator energi dalam meningkatkan mutu lingkungan memperoleh nilai presentase $29,16 \%$ dengan kategori sangat rendah. Untuk indicator dampak energi memperoleh nilai presentase $17,08 \%$ dengan kategori sangat rendah.
\end{abstract}

Kata kunci-Literasi sains, Pembelajaran fisika

\begin{abstract}
The purpose of this study was to provide an overview of the ability of student senior high school of scientific literacy especially in the city of Kendari.The research subjects were concentrated in senior high school 1 Kendari with a total of 350 subjects. The topic of the lesson used was energy. This type of research used descriptive quantitative approach.Data collection techniques use tests which included aspects of context, content, and process. While the data analysis technique used descriptive statistics. The results of the investigation found that the scientific literacy ability of class $\mathrm{X}$ students in Senior High School 1 Kendari on the indicator aspect of content where the first indicator was the change in energy obtains a percentage of $70.83 \%$ with a sufficient category. Then for alternative fuel indicators got a percentage value of $79.72 \%$ with a good category. As for the energy supply molecular indicator, it s a percentage of $33.75 \%$ with a very low category. The ability of scientific literacy in class X students in Senior High School 1 Kendari in the process aspect indicator where the first indicator identifies scientific issues obtains a percentage value of $50.13 \%$ with low. Then, to explain scientific phenomena acquire indicator value percentage of $34.62 \%$ with a very low category. As for the indicator using scientific evidence obtained percentage value of $52.69 \%$ with a lower category. While the scientific literacy ability of class X students in Senior High School 1 Kendari on the indicator of context aspects where the first indicator of energy application in the technology field obtained a percentage value of $89.72 \%$ with a very good category. Then for the energy indicator in improving environmental quality, the percentage value is $29.16 \%$ with a very low category. To obtain the energy impact indicator value percentage of $17.08 \%$ with a very low category.
\end{abstract}

Keywords_-Science literacy, Physics learning 


\section{PENDAHULUAN}

Kemajuan teknologi diera globalisasi ini sangat berkembang pesat, sehingga perlu diimbangi dengan penguasaan ilmu pengetahuan sains agar individu dapat berpartisipasi secara penuh dalam masyarakat di mana ilmu pengetahuan dan teknologi memiliki peran yang sangat penting (1-3). Faktor yang mempengaruhi perkembangan ilmu pengetahuan dan teknologi zaman sekarang adalah kemampuan yang berhubungan dengan penguasaan sains. Kemampuan penguasaan sains sendiri sering dimunculkan istilah literasi sains (4). Peserta didik dikatakan literate jika mampu menguasai 3 dimensi dalam literasi sains yaitu konten, proses dan konteks (5).

Programe for International Student Assessment (PISA) menetapkan tiga dimensi literasi sains dalam pengukurannya, yakni konten sains, proses sains dan konteks sains (6). Konten sains merujuk pada konsep-konsep kunci yang diperlukan untuk memahami fenomena alam dan perubahan yang dilakukan terhadap alam melalui akitivitas manusia (7). Proses sains merujuk pada proses mental yang terlibat ketika menjawab suatu pertanyaan atau memecahkan masalah, seperti mengidentifikasi bukti serta menerangkan kesimpulan (8). Adapun konteks sains menurut PISA merujuk dalam situasi kehidupan umum yang lebih luas dan tidak terbatas pada kehidupan di sekolah saja (5). Secara umu Di Indonesia kondisi berliterasi sudah diterapkan di sekolah-sekolah. Namun, dari hasil studi awal melaporkan bahwa kempampuan literasi khusunya kemampuan literasi sains peserta didik di beberapa sekolah di Indonesia juga masih tergolong rendah $(9,10)$.

Beberapa penelitian yang relevan mengenai literasi sains juga telah dilakukan, seperti hasil penelitian Siagian et al. (11) ditemukan bahwa kemampuan keterampilan literasi sains siswa di Kabupaten Labuhanbatu Utara berdasarkan dimensi literasi sains (konten, proses, dan konteks) berada pada kategori rendah. Selanjutnya, Rusilowati et al. (12) profil literasi sains siswa rendah seperti yang ditunjukkan oleh persentase penguasaan literasi ilmiah di bawah 50\% untuk setiap kategori. Kemudian, Aryani et al. (13) mengatakan bahwa hasil kemampuan literasi sains siswa pada aspek konten dan proses tergolong rendah. Kemudian penelitian yang dilakukan oleh Hajar, et al. (14) menyatakan bahwa kemampuan literasi sains siswa SMA di Kota Bandung tergolong rendah dan penelitian yang dilakukan oleh Odja \& Payu (15) menyatakan bahwa kemampuan literasi sains siswa pada aspek konten, proses, dan konteks termaksud dalam ketegori rendah. Pembagian kriteria kemampuan peserta didik berdasarkan kriteria interpretasi skor (16).

Penelitian ini dimaksudkan untuk melihat seperti apa kemampuan literasi sains peserta didik. Sebagaimana yang telah diuraikan bahwa sekolah yang sudah menerapkan kondisi berliterasi tidak akan menjamin kemampuan literasi sainsnya juga akan baik. Salah satu sekolah yang telah menerapkan kondisi berliterasi sains yaitu SMAN I Kendari. Selain itu, dari hasil observasi yang dilakukan di SMAN 1 Kendari ini juga belum dilakukan penelitian mengenai literasi sains. Maka dari itu peneliti bermaksud melakukan penelitian di SMAN 1 Kendari dengan judul penelitian Deskripsi Kemampuan Literasi Sains Peserta Didik Kelas X di SMAN 1 Kendari Mengenai Energi. Pokok permasalahan yang akan dikaji pada penelitian in yaitu : (1) Bagaimana persentase jawaban benar pada peserta didik kelas X SMAN 1 Kendari untuk tiap butir soal mengenai energi?; (2) Bagaimana gambaran kemampuan literasi sains peserta didik kelas X SMAN 1 Kendari berdasarkan indikator masing-masing aspek literasi sains mengenai energi?: (3) Bagaimana gambaran kemampuan secara umum dari 3 aspek literasi sains pada peserta didik kelas X SMAN 1 Kendari mengenai energi?. Sehingga dengan kajian ini diharapkan dapat memberikan gambaran kemampuan literasi sains pada peserta didik kelas X SMAN 1 Kendari untuk tiap butir soal khusunya mengenai topik energi.

\section{METODEPENELITIAN}

\subsection{Jenis dan Subjek Penelitian}

Jenis penelitian ini adalah penelitian deskriptif dengan pendekatan kuantitatif. Penelitian ini akan dilaksanakan pada semester genap pada salah satu sekolah di kota kendari yaitu SMAN 1 Kendari. Subjek dari penelitian ini adalah seluruh kelas $X$ yang terdaftar di semester genap di SMAN 1 Kendari. Subjek penelitian terdiri dari 365 siswa dari 10 kelas X MIPA dengan masingmasing siswa 36 orang per kelas. 


\subsection{Teknik Pengumpulan Data}

Data dalam penelitian ini adalah data primer yang dikumpulkan dengan menggunakan soal test literasi sains. Tes ini menggunakan soal adopsi yang telah dikembangkan oleh peneliti sebelumnya dengan jumlah soal sebanyak 20 butir soal dengan nilai validitas 0,60 dan nilai reliabilitasnya 0,75 (17). Rincian soal literasi sains yang digunakan dalam penelitian ini disajikan sebagai berikut.

\subsubsection{Aspek Konten}

Pembagian soal berdasarkan indikator apek konten dapat dilihat pada Tabel 1.

Tabel 1. Pembagian Soal Pada Aspek Konten Literasi Sains

\begin{tabular}{lc}
\hline \multicolumn{1}{c}{ Indikator aspek konten } & Nomor soal \\
\hline Perubahan energi & 15,20 \\
Bahan bakar alternative & 11 \\
Molekul penyedia energy & 3,5 \\
\hline
\end{tabular}

\subsubsection{Aspek Proses}

Pembagian soal berdasarkan indicator apek proses dapat dilihat pada Tabel 2.

Tabel 2. Pembagian Soal Pada Aspek Proses Literasi Sains

\begin{tabular}{lc}
\hline \multicolumn{1}{c}{ Indikator aspek proses } & Nomor soal \\
\hline Mengidentifikasi isu ilmiah & 13,16 \\
Menjelaskan fenomena ilmiah & $6,8,10$ \\
Menggunakan bukti ilmiah & $2,4,18,19$ \\
\hline
\end{tabular}

\subsubsection{Aspek Konteks}

Pembagian soal berdasarkan indicator apek konteks dapat dilihat pada Tabel 3.

Tabel 3. Pembagian Soal Pada Aspek Konteks Literasi Sains

\begin{tabular}{lc}
\hline \multicolumn{1}{c}{ Indikator aspek konteks } & Nomor soal \\
\hline Aplikasi energi bidang teknologi & 14,17 \\
Energi dalam meningkatkan mutu lingkungan & 9,12 \\
Dampak energy & 7,1 \\
\hline
\end{tabular}

\subsection{Prosedur Penelitian}

Penelitian ini dilakukan dalam tiga tahapan, yakni tahap persiapan, tahap pelaksanaan dan tahap akhir. (1) Tahap Persiapan: a). Menetapkan sekolah tempat penelitian dan melakukan observasi untuk melihat kondisi peserta didik di sekolah tersebut. b. Menentukan dan merumuskan masalah.. c). Mengurus surat izin penelitian: (2) Tahap Pelaksanaan, tahap pelaksanaan terdiri dari (a) Membagikan instrumen yang digunakan yaitu tes kemampuan literasi sains pada peserta didik yang menjadi sampel, (b) Meminta peserta didik mengisi tes kemampuan literasi sains dengan waktu yang telah ditentukan. (3) Tahap Akhir terdiri dari Mengolah data hasil tes literasi sains peserta didik yang menjadi sampe, Menganalisis hasil temuan penelitian, Menarik kesimpulan berdasarkan hasil pengolahan data.

\subsection{Teknik Analisis Data}

Data yang diperoleh dalam penelitian merupakan data kuantitatif, dengan menggunakan teknik analisis data stastistik deskriptif. Analisis deskriptif merupakan suatu analisis stastistik yang digunakan untuk menganalisis data dengan cara mendeskripsikan atau menggambarkan data yang telah terkumpul sebagaimana adanya tanpa bermaksud membuat kesimpulan yang berlaku untuk umum atau generalisasi (18).

\subsubsection{Menghitung Skor Literasi Sains}

Untuk menghitung skor kemampuan literasi sains siswa dapat digunakan rumus pers.1 (19)

$$
N P=\frac{R}{S M} \times 100 \%
$$

dengan $N P$ adalah nilai kemampuan literasi sains, $R$ adalah jumlah skor soal yang dijawab benar, dan $S M$ adalah skor maksimal dari tes.

\subsubsection{Kategori Kemampuan Literasi Sains}

Penafsiran presentase kemampuan literasi sains ini dilakukan berdasarkan kategori menurut Djaali \& Muljono (16) dapat dilihat pada Tabel 4. 
Tabel 4 .Kriteria Interpretasi Skor Literasi Sains

\begin{tabular}{cc}
\hline Interval kriteria & Kriteria \\
\hline $86-100$ & Sangat baik \\
$72-85$ & Baik \\
$58-71$ & Cukup \\
$43-57$ & Rendah \\
$\leq 43$ & Sangat Rendah \\
\hline
\end{tabular}

\section{HASIL DAN PEMBAHASAN}

\subsection{Persentase Peserta Didik Yang Menjawab Benar di Tiap Butir Soal}

Hasil perhitungan persentase siswa yang menjawab soal dengan benar pada tiap butir soal disjikan pada Tabel 5.

Tabel 5. Data Persentase Peserta Didik Yang Menjawab Soal Dengan Benar

\begin{tabular}{cccl} 
Nomor Soal & N & Persentase (\%) yang menjawab benar & \multicolumn{1}{c}{ Kategori } \\
\hline 1 & 239 & 66,4 & Cukup \\
2 & 24 & 6,67 & Sangat Rendah \\
3 & 306 & 85 & Baik \\
4 & 340 & 94,4 & Sangat Baik \\
5 & 337 & 93,6 & Sangat Baik \\
6 & 12 & 3,33 & Sangat Rendah \\
7 & 346 & 96,1 & Sangat Baik \\
8 & 121 & 33,6 & Sangat Rendah \\
9 & 271 & 75,3 & Baik \\
10 & 287 & 79,72 & Baik \\
11 & 166 & 46,1 & Rendah \\
12 & 198 & 55 & Rendah \\
13 & 96 & 26,7 & Sangat Rendah \\
14 & 112 & 31,1 & Sangat Rendah \\
15 & 84 & 23,3 & Sangat Rendah \\
16 & 93 & 25,8 & Sangat Rendah \\
17 & 150 & 41,67 & Sangat Rendah \\
18 & 95 & 26,4 & Sangat Rendah \\
19 & 39 & 10,83 & Sangat Rendah \\
20 & 191 & 53,1 & Rendah \\
Rata-rata & & Rendah \\
\hline
\end{tabular}

*N=Nilai yang diperoleh

Berdasarkan Tabel 5 menunjukkan bahwa ketercapaian kemampuan literasi sains pada soal yang mampu dijawab peserta didik dengan kategori sangan baik sebanyak 3 butir soal, yang mampu dijawab dengan kategori baik sebanyak 3 butir soal, yang mampu dijawab dengan kategori cukup sebanyak 1 butir soal, yang mampu dijawab dengan kategori rendah sebanyak 3 butir soal, sedangkan yang mampu dijawab dengan kategori sangat rendah sebanyak 10 butir soal.

Dilihat dari Tabel 6 menunjukkan bahwa ketercapaian kemampuan literasi sains pada soal yang mampu dijawab peserta didik dengan kategori sangan baik sebanyak 3 butir soal, yang mampu dijawab dengan kategori baik sebanyak 3 butir soal, yang mampu dijawab dengan kategori cukup sebanyak 1 butir soal, yang mampu dijawab dengan kategori rendah sebanyak 3 butir soal, sedangkan yang mampu dijawab dengan kategori sangat rendah sebanyak 10 butir soal.

Soal yang diberikan diisi dan dijawab keseluruhan oleh perserta didik. Nomor 19 dari soal yang diberikan yang akan dijadikan alat ukur dimana pada soal nomor 19 ini persentase peserta didik vang meniawab soal dengan benar adalah $10.83 \%$ dengan kategori sangat rendah. Hal serupa juga Kemampuan Literasi Sains Siswa SMA di Kota Kendari : Deskripsi dan Analysis

Erniwati, Istijarah, La Tahang, Hunaidah, Vivi Hastuti Rufa Mongkito, Suritno Fayanto 
diperoleh pada kajian Winata et al. (20) bahwa kemampuan literasi mahasiswa masih tergolong rendah terutama pada aspek pemecahan masalah. Hal ini didukung dari hasil investigasi bahwa banyak siswa belum mampu memecahkan masalah yang dihadapinya terutama berkaitan pada konsep. Pantiwati \& Hasamah (21) melaporkan bahwa literasi sains pada penggunaan konsep berada paka indicator sedang sedangkan pada indicator penggunaan sains berupa pemecahan masalah dan analisis grafik berada pada kategori rendah. Tentu ini merupakan bagian yang perlu diperhatikan. Hal dikarenakan dalam proses literasi siswa harus mampu memahami makna konsep yang diberikan sehingga siswa mampu memecahkan masalah yang diberikan.

\subsection{Kemampuan Literasi Sains Peserta Didik Masing-Masing Indikator Aspek Literasi Sains}

Ketercapaian kemampuan literasi sains peserta didik berdasarkan indicator dari 3 aspek literasi sains diperoleh dengan menghitung rata-rata persentase peserta didik yang menjawab soal dengan benar pada tiap-tiap butir soal dari masing-masing indicator aspek.

\subsubsection{Aspek Konten} Tabel 6.

Hasil perhitungan persentase peserta didik pada tiap indicator aspek konten disajikan pada

Tabel 6. Data Kemampuan Literasi Sains Peserta Didik Kelas X SMAN 1 Kendari Pada Tiap Indikator Aspek Konten

\begin{tabular}{lcc}
\hline \multicolumn{1}{c}{ Indikator aspek konten } & Persentase (\%) & Kriteria \\
\hline Perubahan energi & 70,83 & Cukup \\
Bahan bakar alternative & 79,72 & Baik \\
Molekul penyedia energi & 33,75 & Sangat Rendah \\
\hline
\end{tabular}

Tabel 6 menunjukkan bahwa kemampuan literasi sains peserta didik kelas X di SMAN 1 Kendari pada indicator aspek konten dimana indicator pertama yaitu perubahan energy memperoleh nilai presentase $70,83 \%$ dengan kategori cukup. Kemudian untuk indicator bahan bakar alternative memperoleh nilai presentase $79,72 \%$ dengan kategori baik. Sedangkan untuk indicator molekul penyedia energi memperoleh nilai presentase 33,75\% dengan kategori sangat rendah.

Kemampuan literasi sains peserta didik juga dilihat dari tiap indikator aspek. Dimana pada Tabel 6 yang menunjukkan bahwa kemampuan literasi sains peserta didik kelas X di SMAN 1 Kendari pada indicator aspek konten dimana indicator pertama yaitu perubahan energy memperoleh nilai presentase $70,83 \%$ dengan kategori cukup. Kemudian untuk indicator bahan bakar alternative memperoleh nilai presentase $79,72 \%$ dengan kategori baik. Sedangkan untuk indicator molekul penyedia energi memperoleh nilai presentase 33,75\% dengan kategori sangat rendah.

Sangat rendahnya kemampuan literasi sains peserta didik pada aspek konten untuk indikator ketiga disebabkan kurangnya pemahaman konsep peserta didik dalam menjawab soal-soal. Contohnya pada soal nomor 3 (soal yang digunakan sebagai alat ukur dalam penelitian ini) yang membahas tentang molekul penyedia energi dimana merupakan soal yang meminta jawaban dengan memahami konsep yang ada pada artikel bacaan. Kurangnya penguasaan konsep ini menyebabkan banyak konsep-konsep yang dipahami secara salah (miskonsepsi) atau hanya sekedar dihafalkan sehingga konsep tersebut mudah dilupakan. Hal ini sejalan dengan kajian yang dilakukan oleh Nofiana (22) bahwa rendahnya pemahan konsep akan berdampak pada penguasaan konsep. Ia mendapatkan bahwa rendahnya salah satu aspek pada literasi mempengaruhi aspek literasi yang lainnya. Sedangkan Arisman (23) melaporkan bahwa aspek konten sangat penting dalam menunjang literasi selama proses pembelajaran. Aspek konten yang memadai dalam proses pembelajaran memberikan kepada siswa untuk lebih mudah memahami materi.

\subsubsection{Aspek Proses} Tabel 7.

Hasil perhitungan persentase peserta didik pada tiap indicator aspek proses disajikan pada

Tabel 7. Data Kemampuan Literasi Sains Peserta Didik Kelas X SMAN 1 Kendari Pada Tiap Indikator Aspek Proses

\begin{tabular}{lcc}
\hline \multicolumn{1}{c}{ Indikator aspek proses } & Persentase $(\%)$ & Kriteria \\
\hline mengidentifikasi isu ilmiah & 50,13 & Rendah \\
menjelaskan fenomena ilmiah & 34,62 & Sangat Rendah
\end{tabular}




\begin{tabular}{ccc}
\hline Indikator aspek proses & Persentase (\%) & Kriteria \\
\hline menggunakan bukti ilmiah & 52,69 & Rendah \\
\hline
\end{tabular}

Tabel 7 menunjukkan bahwa kemampuan literasi sains peserta didik kelas $\mathrm{X}$ di SMAN 1 Kendari pada indicator aspek proses dimana pada indicator pertama mengidentifikasi isu ilmiah memperoleh nilai presentase 50,13\% dengan rendah. Kemudian untuk indicator menjelaskan fenomena ilmiah memperoleh nilai presentase 34,62\% dengan kategori sangat rendah. Sedangkan untuk indicator menggunakan bukti ilmiah memperoleh nilai presentase 52,69\% dengan kategori rendah.

Kemudian untuk setiap indikator aspek proses dapat dilihat pada Tabel 8 menunjukkan bahwa kemampuan literasi sains peserta didik kelas X di SMAN 1 Kendari pada indicator aspek konteks dimana pada indicator pertama aplikasi energi bidang teknologi memperoleh nilai presentase $89,72 \%$ dengan kategori sangat baik. Kemudian untuk indicator energi dalam meningkatkan mutu lingkungan memperoleh nilai presentase $29,16 \%$ dengan kategori sangat rendah. Untuk indicator dampak energi memperoleh nilai presentase $17,08 \%$ dengan kategori sangat rendah. Sedangkan indikator energi bagi mahkluk hidup memperoleh nilai presentase $26,18 \%$ dengan kategori sangat rendah. Sangat rendahnya kemampuan peserta didik kelas X SMAN 1 Kendari pada aspek proses untuk indikator tersebut salah satunya disebabkan karena kurangnya kemampuan peserta didik dalam pengaplikasian pengetahuan sains pada situasi yang diberikan seperti pada soal nomor 4 .

Aspek proses merupakan salah satu bagian terpenting siswa dalam memecakan masalah. Aspek proses berkenaan dengan bagaimana cara siswa mempu menyelesaikan sebuah permasalahn yang diberikan. Ardianto \& Rubini (24) melaporkan bahwa aspek proses perkenaan dengan bagaimana sebelum pembelajaran dan sesudah pembelajaran berjalan. Sedangkan Yuliati (25) mengemukakan bahwa aspek proses berkenaan dengan bagaimana seorang siswa atau individu mampu mengaplikasikan pengetahuannya dalam dunia nyata.

\subsubsection{Aspek Konteks} Tabel 8.

Hasil perhitungan persentase peserta didik pada tiap indicator aspek konteks disajikan pada

Tabel 8. Data Kemampuan Literasi Sains Peserta Didik Kelas X SMAN 1 Kendari Pada Tiap Indikator Aspek Konteks

\begin{tabular}{lcc}
\hline \multicolumn{1}{c}{ Indikator aspek konteks } & Persentase (\%) & Kriteria \\
\hline Aplikasi energi bidang teknologi & 89,72 & Sangat Baik \\
Energi dalam meningkatkan mutu & 29,16 & Sangat Rendah \\
lingkungan & 17,08 & Sangat Rendah \\
Dampak energi &
\end{tabular}

Tabel 8 menunjukkan bahwa kemampuan literasi sains peserta didik kelas X di SMAN 1 Kendari pada indicator aspek konteks dimana pada indicator pertama aplikasi energi bidang teknologi memperoleh nilai presentase $89,72 \%$ dengan kategori sangat baik. Kemudian untuk indicator energi dalam meningkatkan mutu lingkungan memperoleh nilai presentase 29,16\% dengan kategori sangat rendah. Untuk indikator dampak energi memperoleh nilai presentase $17,08 \%$ dengan kategori sangat rendah.

Kemudian untuk setiap indikator aspek konteks dapat dilihat pada Tabel 8 menunjukkan bahwa kemampuan literasi sains peserta didik kelas X di SMAN 1 Kendari pada indicator aspek konteks dimana pada indicator pertama aplikasi energi bidang teknologi memperoleh nilai presentase $89,72 \%$ dengan kategori sangat baik. Kemudian untuk indicator energi dalam meningkatkan mutu lingkungan memperoleh nilai presentase $29,16 \%$ dengan kategori sangat rendah. Untuk indicator dampak energi memperoleh nilai presentase $17,08 \%$ dengan kategori sangat rendah.

Kemampuan literasi sains peserta didik pada aspek konteks yang menunjuk pada situasi yang menjadi lahan bagi pengaplikasian proses dan pemahaman konsep. Sangat rendahnya kemampuan siswa kelas X SMAN 1 Kendari pada aspek konten untuk kedua indikator tersebut disebabkan kurangnya pemahaman konsep dan proses yang diajarkan. Seperti pada soal nomor 7 peserta didik belum dapat memahami konsep apa yang ada pada artikel dan bagaimana hubungan grafik yang ada. Pada aspek konteks siswa harus bisa menyelesaikan masalah secara kontekstual. Sujana (26) 
berpendapat bahwa dalam literasi penekanannya hendaknya tidak hanya terletak pada aspek konten melainkan juga terhadap aspek konteks. Karena secara harafiah aspek konteks erat kaitannya dengan perubahan mengenai sebuah kemampuan terutama dalam berpikir logis dan rasional

\subsection{Rata-Rata Kemampuan Peserta Didik secara Umum Dari 3 Aspek Literasi Sains}

Ketercapaian kemampuan literasi sains peserta didik berdasarkan 3 aspek diperoleh dengan menghitung rata-rata persentase pada tiap indikator soal dari masing-masing aspek. Hasil perhitungan persentase peserta didik pada tiap aspek disajikan pada Tabel 9.

Tabel 9. Data Rata-Rata Kemampuan Literasi Sains Peserta Didik Kelas X SMAN 1 Kendari

\begin{tabular}{ccc}
\hline Aspek literasi sains & $\begin{array}{c}\text { Persentase (\%) kemampuan } \\
\text { peserta didik }\end{array}$ & Kategori \\
\hline Konten & 61,43 & Cukup \\
Proses & 45,81 & Rendah \\
Konteks & 45,32 & Rendah \\
Rata-rata & $\mathbf{5 0 , 8 5}$ & Rendah \\
\hline
\end{tabular}

Berdasarkan Tabel 9 menunjukkan bahwa rata-rata kemampuan literasi sains secara menyeluruh memperoleh nilai presentase 50,85\% dengan kategori kemampuan rendah. Dimana pada aspek konten peserta didik kelas X di SMAN 1 Kendari memperoleh nilai presentase 61,43\% dengan kategori cukup. Kemudian untuk kemampuan literasi sains peserta didik pada aspek proses memperoleh nilai presentase $45,81 \%$ dengan kategori rendah. Sedangkan untuk kemampuan literasi sains peserta didik pada aspek konteks memperoleh nilai presentase 45,32\% dengan kategori rendah. Dilihat pada Tabel 9 menunjukkan bahwa rata-rata kemampuan literasi sains secara menyeluruh memperoleh nilai presentase 50,85\% dengan kategori kemampuan rendah. Dimana pada aspek konten peserta didik kelas X di SMAN 1 Kendari memperoleh nilai presentase 61,43\% dengan kategori cukup. Kemudian untuk kemampuan literasi sains peserta didik pada aspek proses memperoleh nilai presentase $45,81 \%$ dengan kategori rendah. Sedangkan untuk kemampuan literasi sains peserta didik pada aspek konteks memperoleh nilai presentase 45,32\% dengan kategori rendah.

Rendahnya kemampuan literasi sains secara keseluruhan sangat berkaitan dengan rendahnya kemampuan masing-masing aspek. Ibrahim \& Aspar (27) mengemukakan adanya keterkaitan antara dimensi-dimensi literasi sains. Rendahnya salah satu dimensi literasi sains akan berpengaruh terhadap dimensi literasi sains lainnya. Hal ini menyebabkan siswa hanya mampu menjawab pertanyaan tentang tingkat literasi sains ke FSL (Functional Scientific Literacy) dan sulit untuk mencapai level MSL (Multidimensional Scientific Literacy) yang membutuhkan lebih jawaban yang kompleks (28). Kemampuan literasi sains peserta didik kelas X di SMAN 1 Kendari yang tergolong rendah maka penelitian ini sejalan dengan penelitian-penelitian yang telah dilakukan sebelumnya seperti hasil penelitian Siagian et al. (11) bahwa kemampuan keterampilan literasi sains siswa di Kabupaten Labuhanbatu Utara berdasarkan dimensi literasi sains (konten, proses, dan konteks) berada pada kategori rendah. Kemudian hasil penelitian Rusilowati et al. (12) profil literasi sains siswa rendah seperti yang ditunjukkan oleh persentase penguasaan literasi ilmiah di bawah 50\% untuk setiap kategori. Penelitian yang dilakukan oleh Aryanti et al. (13) mengatakan bahwa hasil kemampuan literasi sains siswa pada aspek konten dan proses tergolong rendah. Kemudian penelitian yang dilakukan oleh Hajar et al. (14) menyatakan bahwa kemampuan literasi sains siswa SMA di Kota Bandung tergolong rendah. Hal serupa dilaporkan oleh Purwani et al.(29) bahwa keterampilan literasi sains siswa rendah terhadap dimensi sains. Sedangkan Rokhmah et al. (30) mengemukakan bahwa terdapat faktor utama yang memengaruhi literasi sains siswa adalah sumber belajar (mis. Buku) dan program pembelajaran itu mendukung mereka untuk memiliki keterampilan literasi sains. Fakta menunjukkan bahwa siswa memiliki lebih banyak waktu untuk berinteraksi dengan buku teks daripada dengan guru.

Berdasarkan ketiga aspek yang diuraikan dapat dikatakan bahwa tidak ada perbedaan signifikan antara ketiga kompetensi tersebut. Dimana pada ketiga aspek tersebut menjelaskan bahwa 
kemampuan literasi sains peserta didik kelas X SMAN 1 Kendari masih dalam kategori rendah. Hal ini berdasarkan beberapa factor penyebab dari masing-masing aspek. Dan tiap aspek literasi sains ada keterkaitan sehingga jika salah satu apek rendah maka akan mempengaruhi aspek literasi sains lainnya.

\section{SIMPULANDANSARAN \\ 4.1 Kesimpulan}

Berdasarkan hasil investigasi mengenai kemampuan literasi diperoleh bahwa Rata-rata kemampuan literasi sains secara menyeluruh memperoleh nilai presentase 50,85\% dengan kategori rendah. Dimana pada aspek konten peserta didik kelas X di SMAN 1 Kendari memperoleh nilai presentase $61,43 \%$ dengan kategori cukup. Kemudian untuk kemampuan literasi sains peserta didik pada aspek proses memperoleh nilai presentase 45,81\% dengan kategori rendah. Sedangkan untuk kemampuan literasi sains peserta didik pada aspek konteks memperoleh nilai presentase 45,32\% dengan kategori rendah

\subsection{Saran}

Dari hasil investigasi maka beberapa yang perlu diperhatikan untuk studi berikutnya adalah (1) Sebaiknya guru lebih memperhatikan kompetensi literasi sains siswa sebagai hasil dari kemampuan literasi sains siswa. (2) Bagi peneliti selanjutnya sebaiknya mengukur kemapuan literasi sains siswa dengan menggunakan materi baru, atau menggunakan metode maupun pendekatan yang mengacu pada tujuan tercapainya literasi sains sehingga siswa dapat mengaplikasikan keterampilan konsep fisika dalam kehidupan sehari-hari dan suatu saat dapat bersaing secara global.

\section{UCAPAN TERIMA KASIH}

Penulis mengucapkan banyak terima kasih kepada SMA 1 Kendari atas dukungannya selama proses penelitian berlangsung. Penulis pula mengucapkan terima kasih kepada Jurusan Pendidikan Fisika atas sumbangsih dalam pengembangan kajian yang dilakukan, sehingga investigasi ini dapat terselesaikan pada tepat waktu.

\section{DAFTAR PUSTAKA}

1. Sukariasih L, Erniwati E, Salim A. Development of Interactive Multimedia on Science Learning Based Adobe Flash CS6. Int J Educ Vocat Stud. 2019;1(4):1-6.

2. Fayanto S, Kawuri MYRT, Jufriansyah A, Setiamukti DD, Sulisworo D. Implementation ELearning Based Moodle on Physics Learning in Senior High School. Indones J Sci Educ. 2019;3(2):93.

3. Fayanto S, Misrawati M, Sulisworo D, Istiqomah HFN, Sukariasih L. The Implementation of Multimedia on Physics Learning Based on Direct Instruction Model in The Topic of Light. Indones J Learn Educ Couns. 2019;1(2):124-32.

4. Winarti W, Liliawati W, Rusnayati H SJ. Literasi Sains Siswa SMP di Kota Bandung Pada Tema Alam Semesta. Semin Nas IPA Pascasarj. 2016;1(1):504.

5. Pratiwi S, C Cari, AMinah N. Pembelajaran IPA Abad 21 dengan Literasi Sains Siswa. Jurnal Materi dan Pembelajaran Fisika. InProsiding Semin Nas IPA Pascasarj UM. 2016;1(1):504.

6. Afni N, Rokhimawan MA. Literasi Sains Peserta Didik Kelas V di MIN Tanuraksan Kebumen. Al-Bidayah J Pendidik Dasar Islam. 2018;10(1):47-68.

7. Nofiana M, Julianto T. Upaya Peningkatan Literasi Sains Siswa Melalui Pembelajaran Berbasis Keunggulan Lokal. Biosf J Tadris Biol. 2018;9(1):24-35.

8. Zuriyani E. Literasi sains dan pendidikan. Kemenag Sumses. 2011. p. 1-2. 
9. Sukowati D, Rusilowati A. Analisis Kemampuan Literasi Sains Dan Metakogntif Peserta Didik. Phys Commun. 2017;1(1):16-22.

10. Peringkat dan Capaian PISA Indonesia Mengalami Peningkatan. Kemterian Pendidikan dan Kebudayaan. 208AD. p. 1-2.

11. Siagian P, Silitonga M, Djulia E. Scientific Literacy Skills of Seventh Grade Junior High School ( SMP Negeri ) Students in North Labuhanbatu Regency. Int J Humanit Soc Sci Educ. 2017;4(11):176-82.

12. Rusilowati A, Kurniawati L, Nugroho SE, Widiyatmoko A. Developing an instrument of scientific literacy asessment on the cycle theme. Int J Environ Sci Educ. 2016;11(12):571827.

13. Intan A, Ariyanti P, Ramli M, Prayitno BA. Preliminary Study On Developing Science Literacy. Pros ICTTE FKIP UNS 2015. 2016;1:284-9.

14. Imani, Hajar A, Ika M. Profil Literasi Siswa SMP di Kota Bandung Terkait Tema Pemanasan Global. Malang; 2016.

15. Odja HA, Payu CS. Analisis Kemampuan Awal Literasi Sains Siswa pada Konsep IPA. Surabaya; 2014.

16. Djaali, P Muljono. Pengukuran dalam Bidang Pendidikan. Jakarta: Program Pascasarjana Universitas Negara Jakarta; 2004. 1-50 p.

17. Adawiyah R, Wisudawati AW. Pengembangan Instrumen Tes Berbasis Literasi Sains : Menilai Pemahaman Fenomena Ilmiah Mengenai Energi. Indones J Curric Educ Technol Stud [Internet]. 2017;5(2):112-21. Available from: http://journal.unnes.ac.id/sju/ index.php/jktp

18. Sujarweni VW, Endrayanto P. Statistika untuk Penelitian. Yogyakarta: Graha Ilmu; 2012. 1$50 \mathrm{p}$.

19. Purwanto N. Prinsip-prinsip dan Teknik Evaluasi Pengajaran. 1th ed. Bandung: PT Remaja Rosdakarya; 2006. 1-50 p.

20. Winata A, Cacik S, Ifa Seftia R W. Analisis Kemampuan Awal Literasi Sains Mahasiswa Pada Konsep IPA. Educ Hum Dev J. 2016;1(1):34-9.

21. Pantiwati Y, H Hasamah. Analisis kemampuan literasi sains siswa SMP Kota Malang. Malang; 2016.

22. Nofiana M. Profil Kemampuan Literasi Sains Siswa SMP di Kota Purwokerto Ditinjau dari Aspek Konten, Proses, dan Konteks Sains. JSSH (Jurnal Sains Sos dan Humaniora). 2017;1(2):77.

23. Arisman AA. Penerapan Pembelajaran Kooperatif Tipe Stad Dengan Metode Praktikum Dan Demonstrasi Multimedia Interaktif Dalam Pembelajaran Ipa Terpadu Untuk Meningkatkan Literasi Sains Siswa. Edusains. 2016;7(2):179-84.

24. Ardianto D, Bibin Rubini. Literasi Sains Dan Aktivitas Siswa Pada Pembelajaran Ipa Terpadu Tipe Shared. USEJ - Unnes Sci Educ J. 2016;5(1):1167-74.

25. Yuliati Y. Literasi Sains Dalam Pembelajaran IPA. J Chem Inf Model. 2017;3(2):21-8.

26. Sujana A, Permanasari A, Sopandi W, Mudzakir A. Literasi Kimia Mahasiswa PGSD dan Guru IPA Sekolah Dasar. J Pendidik IPA Indones. 2014;3(1):5-11.

27. Ibrahim MA, N H Aspar. Tahap Literasi Sains dalam Kalangan Pelajar Tingkatan Empat Sekolah Akhir Agam di Daerah Hilir Perak. Perak: Universiti Teknologi Melaka; 2006. 1-5 p. 
28. Riskwati, Azis A, Aqil M, Sitti R, Yunus R. Analysis student's level of science literacy in class x sman khusus jeneponto. In: International Conference on Mathematics, Science, and Education. 2015. p. 1-5.

29. Purwani LD, Sudargo F, Surakusumah W. Analysis of student's scientific literacy skills through socioscientific issue's test on biodiversity topics. J Phys Conf Ser. 2018;1013(1):15.

30. Rokhmah A, Sunarno W, Masykuri M. Science Literacy Indicators in Optical Instruments of Highschool Physics Textbooks Chapter. J Pendidik Fis Indones. 2017;13(1):19-24. 